\title{
Seasonal patterns of growth phenology and nutrient dynamics in four matorral shrubs in Central Chile
}

\author{
Patrones estacionales de fenología de crecimiento y dinámica de nutrientes en cuatro \\ arbustos del matorral de Chile central
}

\author{
Philip W. Rundel ${ }^{1 *}$, M. Rasoul Sharifi ${ }^{1}$, Michelle K. Vu ${ }^{1}$, Gloria Montenegro ${ }^{2}$ \& Harold A. Mooney ${ }^{3}$ \\ ${ }^{1}$ Department of Ecology and Evolutionary Biology, University of California, Los Angeles, CA 90095-1606, USA. \\ 2Departamento de Ciencias Vegetales, Facultad de Agronomía e Ingeniería Forestal, Pontificia Universidad Católica de Chile, Santiago, Chile. \\ ${ }^{3}$ Department of Biological Sciences, Stanford University, Stanford, 94305-2204, USA. \\ *Email: rundel@biology.ucla.edu
}

\section{ABSTRACT}

Chile is one of five global regions exhibiting a mediterranean-type climate regime characterized by evergreen sclerophyll shrublands. These matorral shrublands which dominate the foothills and slopes of the Coastal Mountains and foothills of the Andes in central Chile have received much less study than evergreen shrublands in other mediterranean-type climate regions of the world. Phenological development, growth, and nutrient dynamics of the four widespread matorral shrub species, Lithrea caustica (Anacardiaceae), Colliguaja odorifera (Euphorbiaceae), Kageneckia oblonga (Rosaceae), and Retanilla trinervia (Rhamnaceae), were monitored in central Chile from 1971 to 1975 . The four study species all demonstrated growth dynamics and nutrient relations similar to chaparral shrub species of southern California. The species exhibited a sequential development of phenological stages in leaf components following fall precipitation. Colliguaja with relatively shallow root systems showed a sharp peak of new leaf production at the beginning of summer, dropping quickly as summer drought occurred. Another shallowrooted species while Retanilla initiated leaf production in the late winter, earlier than the other two species, and presented a growth pattern dependent on soil moisture availability. Lithrea and Kageneckia, a more deep-rooted species, initiated leaf production in late spring and continued through the summer. Overall, Chilean shrubs exhibited higher nutrient contents than those of chaparral shrubs in California, suggesting a difference in soil nutrient availability. Reproductive tissues represent a significant portion of the new biomass and nutrient allocation in all four matorral shrubs. Biomass allocation of new tissues (i.e. new leaves, new stems and reproductive tissues) ranged from $8.2 \%$ in Retanilla to $16.7 \%$ in Colliguaja. Overall, the phenology and nutrient relations of matorral shrubs were similar to those found in chaparral, shrubs indicating that the similar climate regimes can lead to convergence in leaf traits, phenology, and nutrient relationships.

Keywords: central Chile, matorral, vegetative phenology, reproductive allocation.

\section{RESUMEN}

Chile es una de las cinco regiones en el mundo que presenta clima de tipo mediterráneo, caracterizado por matorrales esclerófilos perennifolios. Estos matorrales arbustivos que dominan las estribaciones y laderas de la Cordillera de la Costa, y las estribaciones de los Andes en Chile central, han sido mucho menos estudiados que los matorrales perennifolios de otras regiones mediterráneas en el mundo. El desarrollo fenológico, el crecimiento y la dinámica en el contenido de nutrientes de las cuatro especies 
arbustivas más ampliamente distribuidas en el matorral de Chile central, Lithrea caustica (Anacardiaceae), Colliguaja odorifera (Euphorbiaceae), Kageneckia oblonga (Rosaceae) y Retanilla trinervia (Rhamnaceae), fueron monitoreadas entre 1971 y 1975. Las cuatro especies mostraron una dinámica de crecimiento y relaciones en el contenido de nutrientes similares a las especies de arbustos del chaparral del sur de California. Las especies exhibieron un desarrollo de estados fenológicos en los componentes foliares, cuya secuencia sigue la caída de precipitaciones. Colliguaja, con un sistema radicular relativamente poco profundo, mostró un marcado punto máximo en la producción de hojas nuevas a comienzos del verano, cayendo rápidamente a medida que llega la sequía del verano. Mientras que otra especie, Retanilla, de raíces poco profundas, inició la producción de hojas a fines del invierno, antes que las otras dos especies, y presentó un patrón de crecimiento dependiente de la disponibilidad de humedad del suelo. Lithrea y Kageneckia, especies de raíces más profundas, iniciaron la producción de hojas a fines de la primavera y continuaron durante el verano. En general, los arbustos chilenos presentan mayores contenidos de nutrientes que los arbustos del chaparral en California, lo que sugiere una diferencia en la disponibilidad de nutrientes del suelo. Los tejidos reproductivos representan una porción significativa de la asignación a biomasa nueva y de nutrientes en las cuatro especies de arbusto del matorral. La asignación de biomasa a tejidos nuevos (i.e., hojas y tallos nuevos, y tejidos reproductivos) varió de 8,2\% en Retanilla a 16,7\% en Colliguaja. En general, la fenología y dinámica del contenido de nutrientes de los arbustos del matorral fueron similares a las encontradas en el chaparral, con arbustos que indican que similares regímenes climáticos pueden conducir a convergencia en rasgos foliares, fenología y relaciones de nutrientes.

Palabras clave: Chile central, matorral, fenología vegetativa, asignación reproductiva.

\section{INTRODUCTION}

Central Chile is one of five global regions exhibiting a Mediterranean-type climate regime with cool wet winters and warm dry summers. The iconic vegetation structure shared by these five regions is that of an evergreen sclerophyll shrubland (Cowling et al. 1996, Rundel et al. 2016). This shrubland in central Chile is termed matorral and in many ways is structurally and environmentally similar to California chaparral (Parker et al. 2016, Keeley \& Davis 2007, Rundel 2018). Matorral shrublands dominate the foothills and slopes of the coastal mountains and foothills of the Andes in central Chile, and grade into other vegetation types with changes in moisture availability or lower temperatures. With lower precipitation along the coast and to the north, a droughtdeciduous component of plant cover is added forming a coastal matorral community. Matorral transitions into a taller sclerophyll woodland community as precipitation increases on upper slopes of the coast range, often with arboreal growth forms of some of the same species, and grades into a lower stature montane matorral shrub land on drier slopes above $1000 \mathrm{~m}$ in the Andes (Rundel 1981, Steward \& Webber 1981.

Matorral shrublands have until recent decades been characterized by an open stand structure with herbaceous cover, the result of traditional land use practices of charcoal burning and grazing by goats (Aschmann \& Bahre 1977). Matorral cover, however, is expanding today with economic development and urbanization of central Chile. Dominant species on more mesic pole-facing slopes include Cryptocarya alba (Molina) Looser (Lauraceae), Colletia hystrix Clos (Rhamnaceae), Kageneckia oblonga Ruiz \& Pav. (Rosaceae), and Lithrea caustica (Molina) Hook. \& Arn. (Anacardiaceae). More xeric equator-facing slopes likewise support Lithrea caustica along with Colliguaja odorifera Molina (Euphorbiaceae), Retanilla trinervia (Gillies \& Hook.) Ruiz \& Pav. (Rhamnaceae), and the drought deciduous Podanthus mitiqui Lindl. (Asteraceae). Also notable are the common presence of the xerophytes Puya berteroniana Mez. and P. chilensis Molina (Bromeliaceae) and Echinopsis chiloensis (Colla) Friedrich \& G.D. Rowley (Cactaceae).

A significant component of the International Biological Program from 1971-76 was a major investigation, Convergent Evolution in Chile and California, that collected detailed ecological and environmental data from paired sites in southern California and central Chile (Mooney et al. 1977, Di Castri \& Mooney 1973). The primary study sites for research were Fundo Santa Laura in central Chile representing matorral ecosystems and Echo Valley in southern California representing chaparral ecosystems. Studies focused on a 
detailed quantitative investigation of the phenology, growth dynamics and nutrient dynamics of six shrub species at each site. As described below in the Methods and Materials, the level of detailed biweekly sampling represented a level of detail and analyses that has not been repeated. An example of this level of detail can be seen is resulting publication on the growth and nutrient dynamics of Adenostoma fasciculatum Hook. \& Arn. (Mooney \& Rundel 1979). Despite this frequency of detailed sampling and rigorous data collection, much of the valuable archived data was never published. This contribution uses the historical IBP database to assess the growth dynamics and nutrient relations in four common species of matorral shrubs.

\section{MATERIALS AND METHODS}

\section{STUDY SITE}

Field studies were carried out at Fundo Santa Laura on the upper east-facing slope of the Cuesta de la Dormida at 1000 $\mathrm{m}$ elevation in the Cordillera de la Costa of central Chile. As a matorral plant community, this region experiences a typical Mediterranean-type climate, with hot warm summers and cold wet winters (Di Castri \& Mooney, 1973). Mean maximum and minimum monthly temperatures and mean monthly precipitation were collected at the study site from April 1971 to December 1974 (Fig. 1). High average temperatures were typical for the warmer months of November to April, with the highest average maximum of $23^{\circ} \mathrm{C}$ occurring in January and February. Low average temperatures were observed in the months from May to October, coinciding with increased precipitation. The lowest average maximum temperature of $11^{\circ} \mathrm{C}$ was recorded in June, the month with the coolest maximum temperature. Mean annual precipitation was 992 $\mathrm{mm}$, and no precipitation was observed during the summer months over the four-year period of the study. Soils are rocky sandy loams with a pH of 6.2 -6.5 (Miller et al. 1977).

\section{STUDY SPECIES}

Four common matorral species were selected for intensive study (Fig. 2). Lithrea caustica (Anacardiaceae) is a widespread and often dominant matorral shrub found broadly across central Chile. It is an extreme generalist occurring on all variations of slopes and exposures from sea level to $1800 \mathrm{~m}$ elevation. While an evergreen matorral shrub 2-3 $\mathrm{m}$ in height at the study site because of past disturbance, it is highly plastic in growth form and can range in canopy architecture from a prostrate shrub on coastal bluffs to a monopodial tree with a trunk diameter of $40 \mathrm{~cm}$ or more in riparian habitats. Colliguaja odorifera (Euphorbiaceae) is a drought-adapted semi-evergreen matorral shrub that is common on xeric northfacing slopes and may be dominant on sites heavily damaged by fire or overgrazing (Rundel 1981). Two other species of Colliguaja replace this species in higher elevation communities of montane matorral. Kageneckia oblonga (Rosaceae) is a shrub or small tree with a wide geographic distribution in central Chile, most typically on less xeric south-facing slopes. As with Colliguaja, this species is replaced by two shrubby congeners on the higher slopes of the Andes in a montane matorral community. Retanilla trinervia (Rhamnaceae; formerly known as Trevoa trinervis) is a widespread drought-deciduous matorral shrub occurring from sea level to elevations over $1500 \mathrm{~m}$. It is particularly characteristic of disturbed habitats with a history of wood-cutting, grazing, or fire.

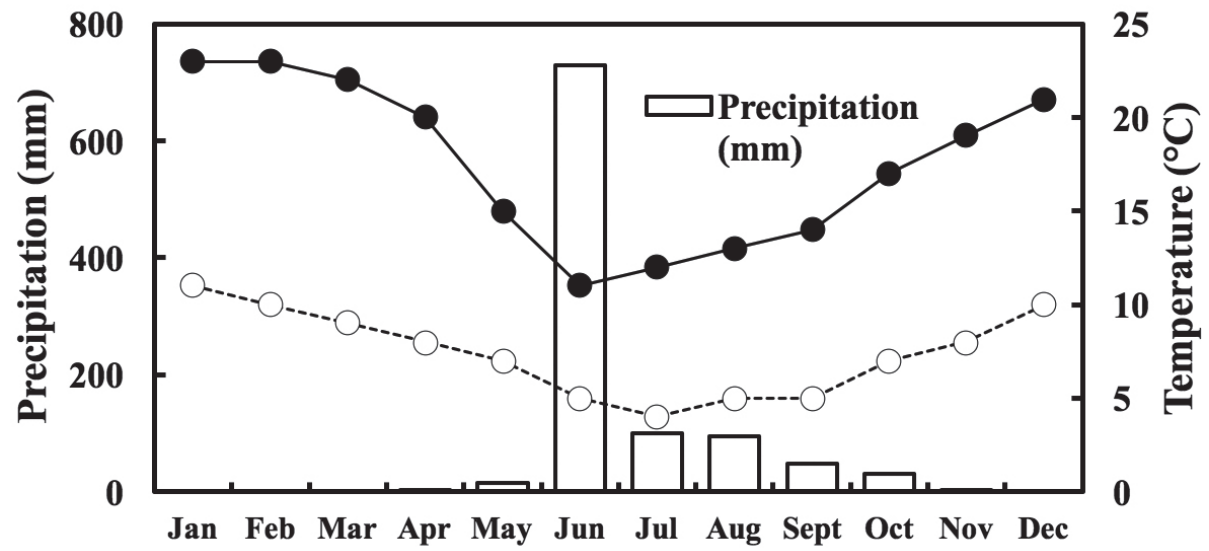

FIgURE 1. Mean monthly maximum and minimum temperature and precipitation for Fundo Santa Laura, Chile for April 1971 to December 1974. / Media mensual de la temperatura máxima y mínima, y precipitaciones para el Fundo Santa Laura, Chile desde abril 1971 a diciembre 1974. 


\section{SAMPLING METHODS}

The individual plants selected for sampling were all moderatesized shrubs 1.0-1.5 $\mathrm{m}$ in height at the time of study, with mean canopy dimensions and aboveground biomass shown in Table 1. Net primary production of shrub species was estimated by sampling 25 individual branches cut from a population of sample shrubs at 2-4-wk intervals from late 1971 through July 1975 (Mooney \& Kummerow 1977). Tissue allocation on these branches was determined for new leaves (beginning in June 1972), new stems, reproductive tissues (flowers and fruits), old leaves (not current season), and old stems for 1972-75. Biomass measurements on new leaves began in June 1972. Biomass per branch was converted to biomass per area of shrub canopy utilizing the number of sample-size branches present in the shrub. After sorting, drying, and weighing, the branch components were pooled into three subsamples and used for the determination of total nitrogen and phosphorus contents. Total nitrogen was determined by the Kjeldahl method and total phosphorus by the molybdate method using a Technicon Autoanalzer II. For estimates of pool sizes of nutrients, the distribution of aboveground tissues taken from total shrub harvests in July 1972 (Giliberto et al. 1977).

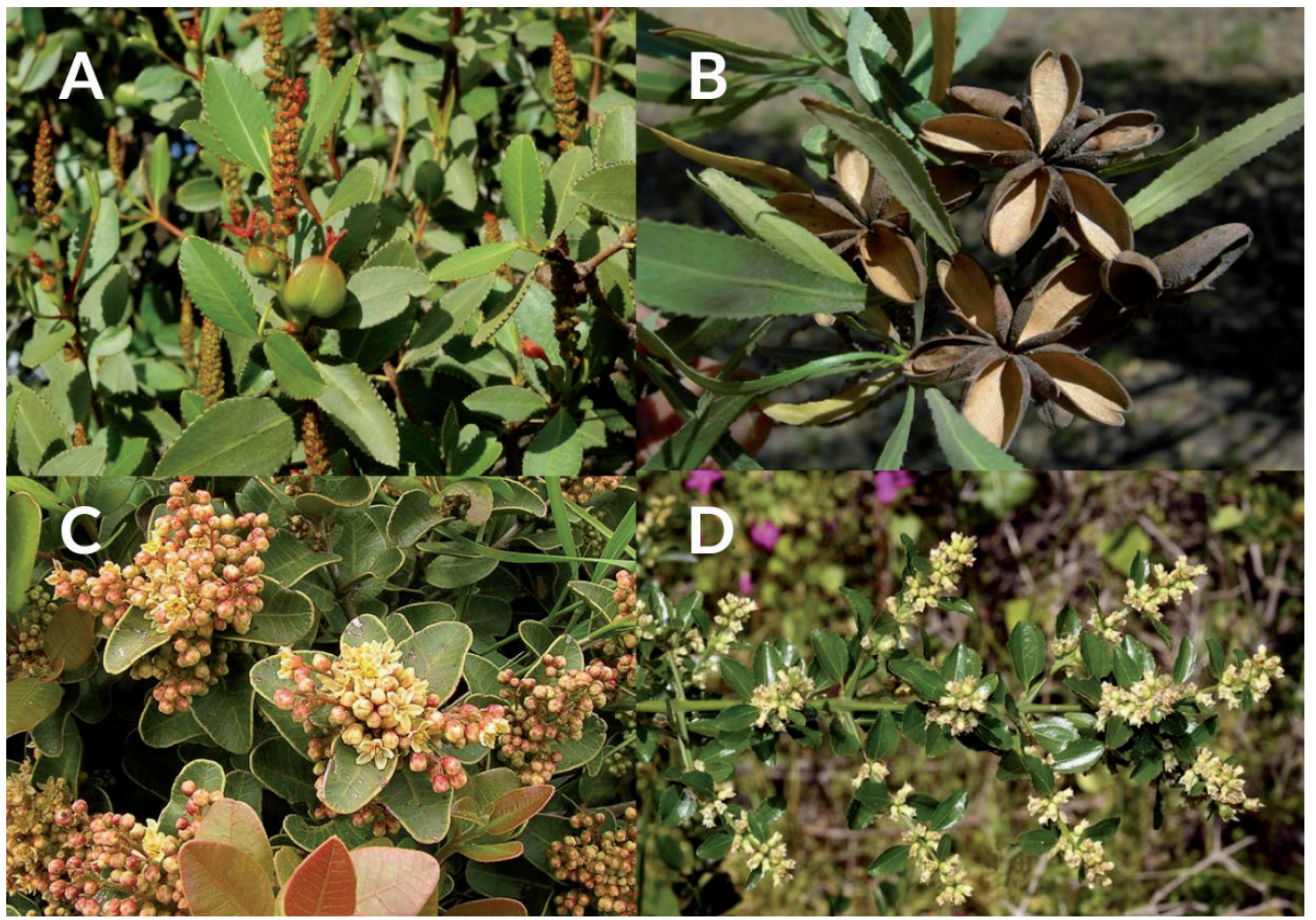

Figure 2. Study species from Fundo Santa Laura, Central Chile: Colliguaja odorifera (A), Kageneckia oblonga (B), Lithrea caustica (C), and Retanilla trinervia (D). / Especies estudiadas en el Fundo Santa Laura, Chile central: Colliguaja odorifera (A), Kageneckia oblonga (B), Lithrea caustica (C) y Retanilla trinervia (D).

TABLE 1. Mean shrub and leaf traits for matorral study shrubs. Data from Mooney et al. (1977). / Media del matorral y de los rasgos foliares en las especies arbustivas estudiadas. Datos de Mooney et al. (1977).

\begin{tabular}{lccccc}
\hline Species & $\begin{array}{c}\text { Aboveground } \\
\text { Height } \\
(\mathrm{m})\end{array}$ & $\begin{array}{c}\text { Diameter } \\
(\mathrm{m})\end{array}$ & $\begin{array}{c}\text { Biomass } \\
\left(\mathrm{gm}^{-2}\right)\end{array}$ & $\begin{array}{c}\text { Leaf area index } \\
\left(\mathrm{m}^{2} \mathbf{~ m}^{-2}\right)\end{array}$ & $\begin{array}{c}\text { Leaf specific weight } \\
\left(\mathrm{mg} \mathrm{cm}^{-2}\right)\end{array}$ \\
\hline Lithrea caustica & 0.80 & 2.09 & 865 & 1.14 & 26 \\
Colliguaja odorifera & 1.12 & 1.94 & 1385 & 0.91 & 27 \\
Kageneckia oblonga & 1.24 & 1.02 & 1341 & 2.24 & 21 \\
Retanilla trinervia & 1.40 & 1.90 & 826 & 2.26 & 8 \\
\hline
\end{tabular}




\section{RESULTS}

\section{Phenology And GRowth}

New leaf biomass in Lithrea reached high levels from January through July and then was reduced through the winter months as these leaves matured (Fig. 3A, 4A). Small amounts of new leaves were present throughout the year. Mature leaf biomass of Lithrea peaked in October and began to decline from abscission in November and December as new leaves were being produced. Typical leaf longevity was two years, but older leaves were sometimes present. Flower production for Lithrea began in September and remained active into December, with small amounts of flowers sampled from January into April (Fig. 5A). Fruit biomass was at its maximum in February with a secondary peak in May.

Colliguaja exhibited a semi-evergreen behavior with new leaf production beginning in the spring and biomass peaking in February. Old leaf biomass accumulated to a maximum in September followed by a slow decline through to December
(Fig. 3B, 4B). Colliguaja maintained its individual old leaves on the canopy for approximately 10 months on average. Flower production peaked sharply during the spring months and reached a maximum in July (Fig. 5B). Fruit production occurred slowly and reached a maximum biomass in January.

Kageneckia exhibited a broad peak of new leaf production beginning in January and produced a high biomass that continued into June (Fig. 3C, 4C). From this peak there was a slow leaf abscission over the winter months as new leaves were formed and matured, indicating a two-year life span for leaves. Unlike Colliguaja, maximum flower biomass of Kageneckia peaked sharply in November, with small scattered production of flowers in the summer months (Fig. 5C). Fruit biomass was at its highest in January and February with small amounts sampled through the summer.

New leaf production in Retanilla began as early as July but sharply increased in August, reaching a maximum biomass from October to December. Leaf abscission occurred rapidly with the onset of summer drought and the shrubs were
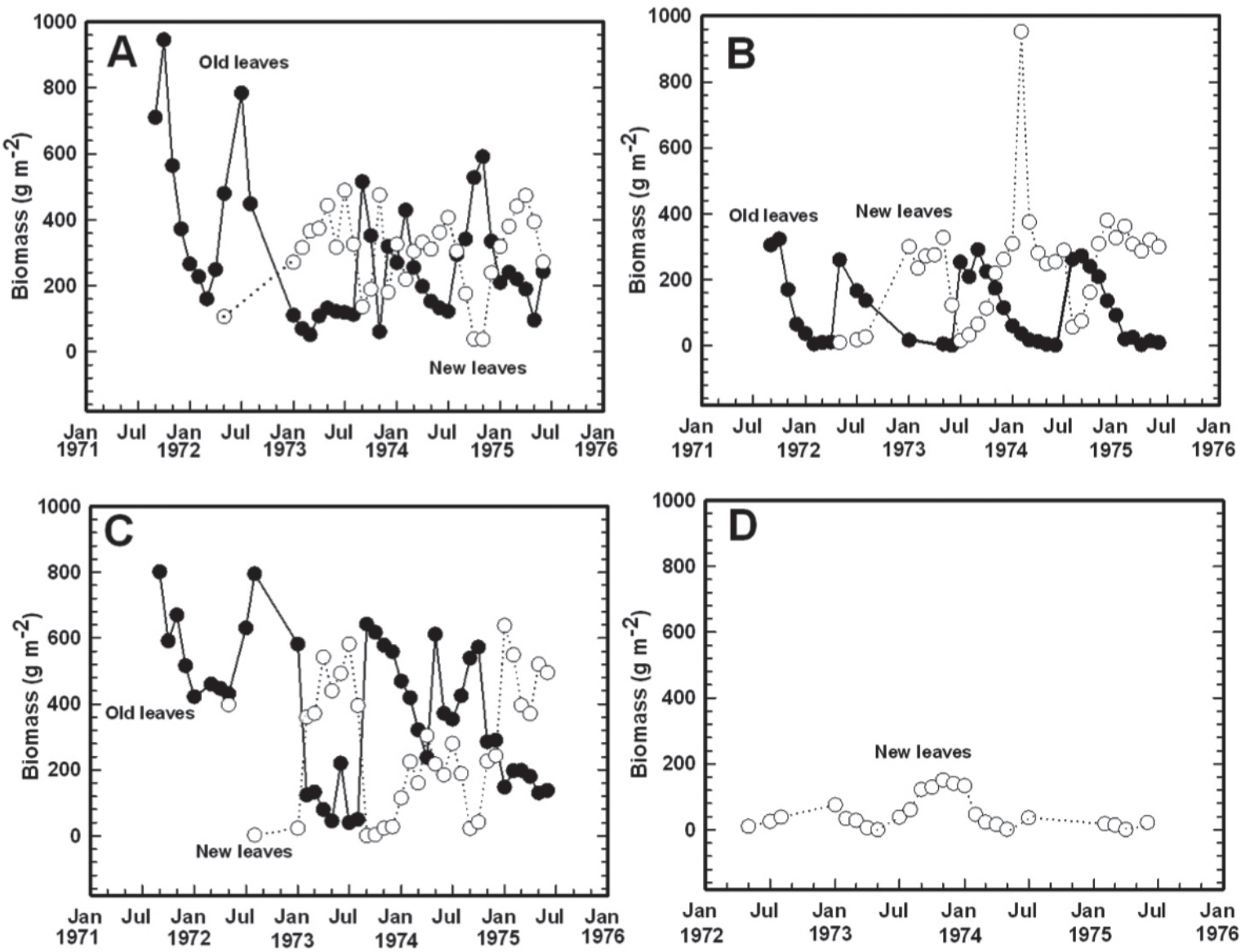

FIGURE 3. Seasonal change in biomass of old and new leaves of Lithrea caustica (A), Colliguaja odorifera (B), Kageneckia oblonga (C), and Retanilla trinervia (D). / Cambios estacionales en la biomasa de hojas viejas y nuevas de Lithrea caustica (A), Colliguaja odorifera (B), Kageneckia oblonga (C) y Retanilla trinervia (D). 
leafless by January (Fig. 3D, 4D). Flowers production in Retanilla peaked sharply in the spring months of September and October (Fig. 5D). Fruit production occurred quickly after flowering, with a maximum biomass collected in December.

\section{NUTRIENT RELATIONSHIPS}

Mature leaves of the three evergreen study species typically exhibited a relatively similar seasonal pattern of nitrogen content with concentrations varying from $0.8-1.0 \%$ in Lithrea to $0.6-1.2 \%$ in Colliguaja and 0.8-1.2\% in Kageneckia. (Fig. 6. New leaves briefly had nitrogen contents as high as $2.2 \%$ in Lithrea and $2.7 \%$ in the other two evergreen shrub species. The nitrogen fixing Retanilla had peak nitrogen contents as high as $4.6-5.5 \%$ in new young leaves but these concentrations dropped rapidly to $1.2-1.6 \%$ as the leaves matured (Fig. 6D).

Seasonal patterns of phosphorus contents of mature leaves

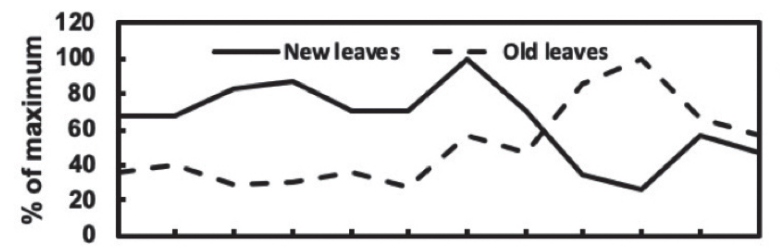

A

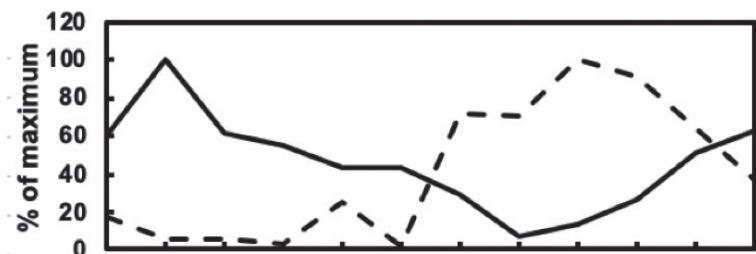

B
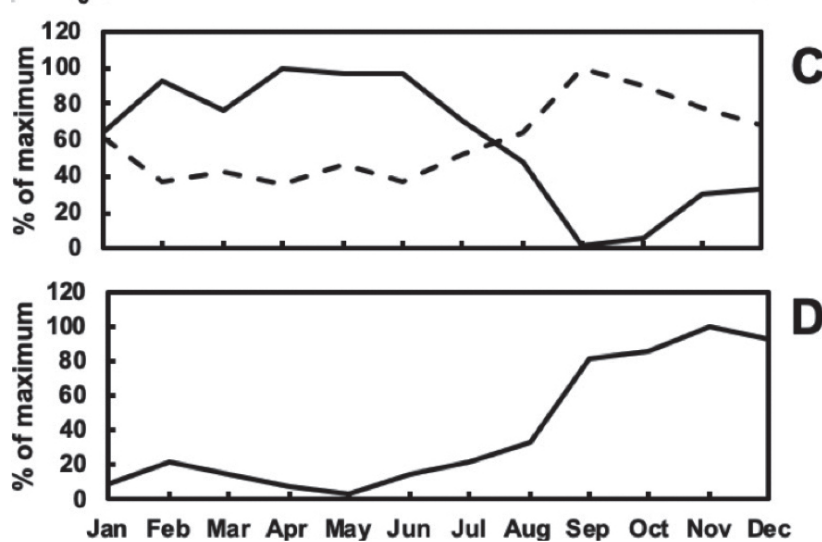

Figure 4. Relative mean monthly leaf biomass from April 1971 to June 1975 plotted as a percentage of maximum biomass during the production of each leaf cohort for Lithrea caustica (A), Colliguaja odorifera (B), Kageneckia oblonga (C), and Retanilla trinervia (D). / Media mensual relativa de la biomasa foliar desde abril 1971 a junio 1975, graficado como porcentaje de la biomasa máxima durante la producción de cada cohorte foliar para Lithrea caustica (A), Colliguaja odorifera (B), Kageneckia oblonga (C) y Retanilla trinervia (D). of Lithrea and Colliguaja typically ranged from 0.06-0.12 (Fig. 7). while phosphorus contents of old leaves of Kageneckia were consistently higher with a range of $0.08-0.18 \%$ (Fig. 7). New leaves briefly had phosphorus contents as high as $0.30 \%$ in Lithrea and Colliguaja, and $0.48 \%$ in Kageneckia, with these levels dropping sharply over a few months to values close to those of old leaves. Newly formed leaves of Retanilla had phosphorus contents as high as $0.40 \%$, but these high concentrations dropped quickly to $0.06-0.10 \%$ as the leaves matured (Fig. 7D).

ReLATIVE TISSUE ALLOCATION OF BIOMASS AND NUTRIENTS

Relative biomass and nutrient allocation in branch samples of the four matorral shrubs showed species-specific differences (Fig. 8A, Table 2). Lithrea heavily allocated biomass to new leaves compared to its other plant components at the

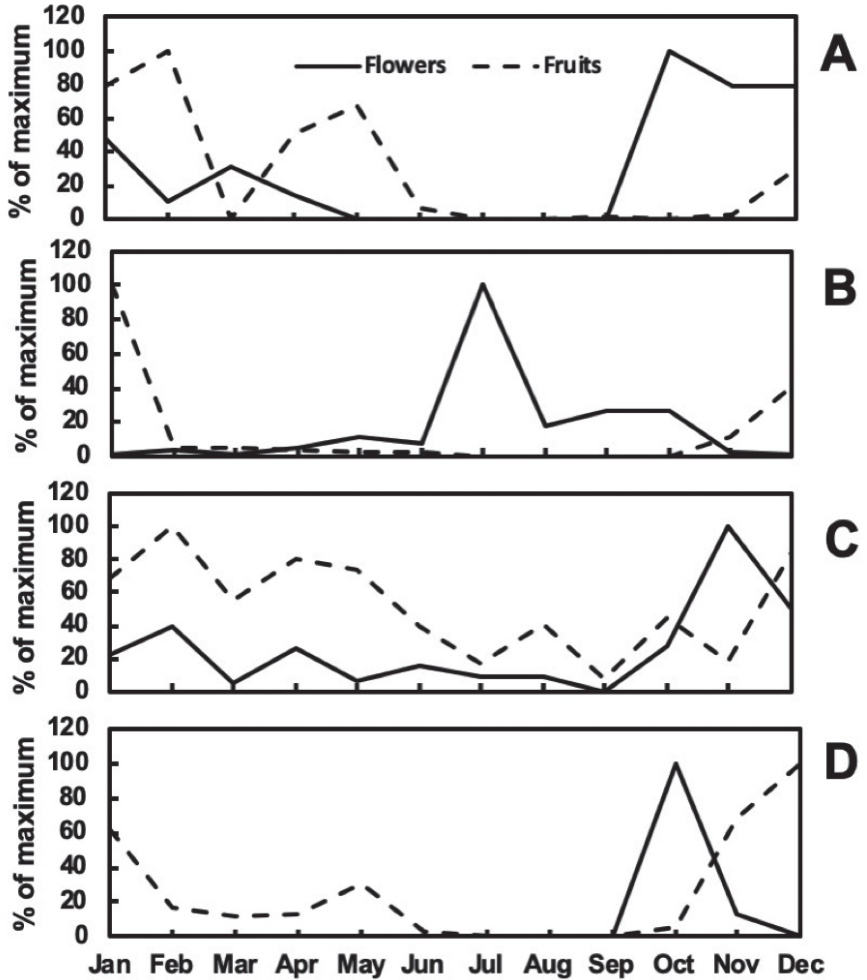

FIGURE 5. Relative mean monthly flower and fruit biomass from April 1971 to June 1975 plotted as a percentage of maximum rate during the production of each leaf cohort for Lithrea caustica (A), Colliguaja odorifera (B), Kageneckia oblonga (C), and Retanilla trinervia (D). / Media mensual relativa de la biomasa de flores y frutos desde abril 1971 a junio 1975, graficado como porcentaje de la biomasa máxima durante la producción de cada cohorte foliar para Lithrea caustica (A), Colliguaja odorifera (B), Kageneckia oblonga (C) y Retanilla trinervia (D). 
beginning of summer, with new leaves constituted $43 \%$ of the total branch biomass. In contrast, a large portion of the biomass of Colliguaja and Retanilla resided in old stems, constituting $45 \%$ and $48 \%$ of the total biomass, respectively, with only $20 \%$ and $22 \%$ allocation of December biomass to new leaves (Table 2). Kageneckia was intermediate in biomass allocation with relatively allocated amount of biomass to new leaves and old stems.

Despite difference in biomass allocation to new leaves, patterns of nitrogen allocation between biomass pools was relatively similar for all four shrub species. Nitrogen allocation to new leaves varied from $24 \%$ in Colliguaya to $30 \%$ in Retanilla (Fig. 8B, Table 2). Phosphorus allocation to new leaves was also relatively even between species ranging from $21 \%$ in Colliguaja to $27 \%$ in Retanilla.
Biomass allocation to reproductive tissues ranged from a low of $4.2 \%$ in Retanilla to a high of $7.2 \%$ in Lithrea (Table 2). However, all four shrub species allocated proportionally higher amounts of nitrogen and phosphorus to these tissues (Fig. 8B, 8C). Nitrogen allocation was 2-3.5 times higher than the proportion of biomass in reproductive tissues with a high of $15.7 \%$ in Retanilla. Phosphorus allocation to reproductive tissues was notably high in Lithrea and Retanilla with $20,5 \%$ and $18.8 \%$, respectively (Table 2). The combined proportion of biomass in new tissues (i.e. new leaves, new stems, and reproductive tissues) ranged from only $32 \%$ in Colliguaja to a high of $68 \%$ in Lithrea. The allocation of nitrogen to new tissues was much more even ranging from $61 \%$ in Lithrea to $79 \%$ for Retanilla. Phosphorus allocation to new tissues was similar varying from $61 \%$ in Colliguaja to $74 \%$ to Retanilla (Table 2).
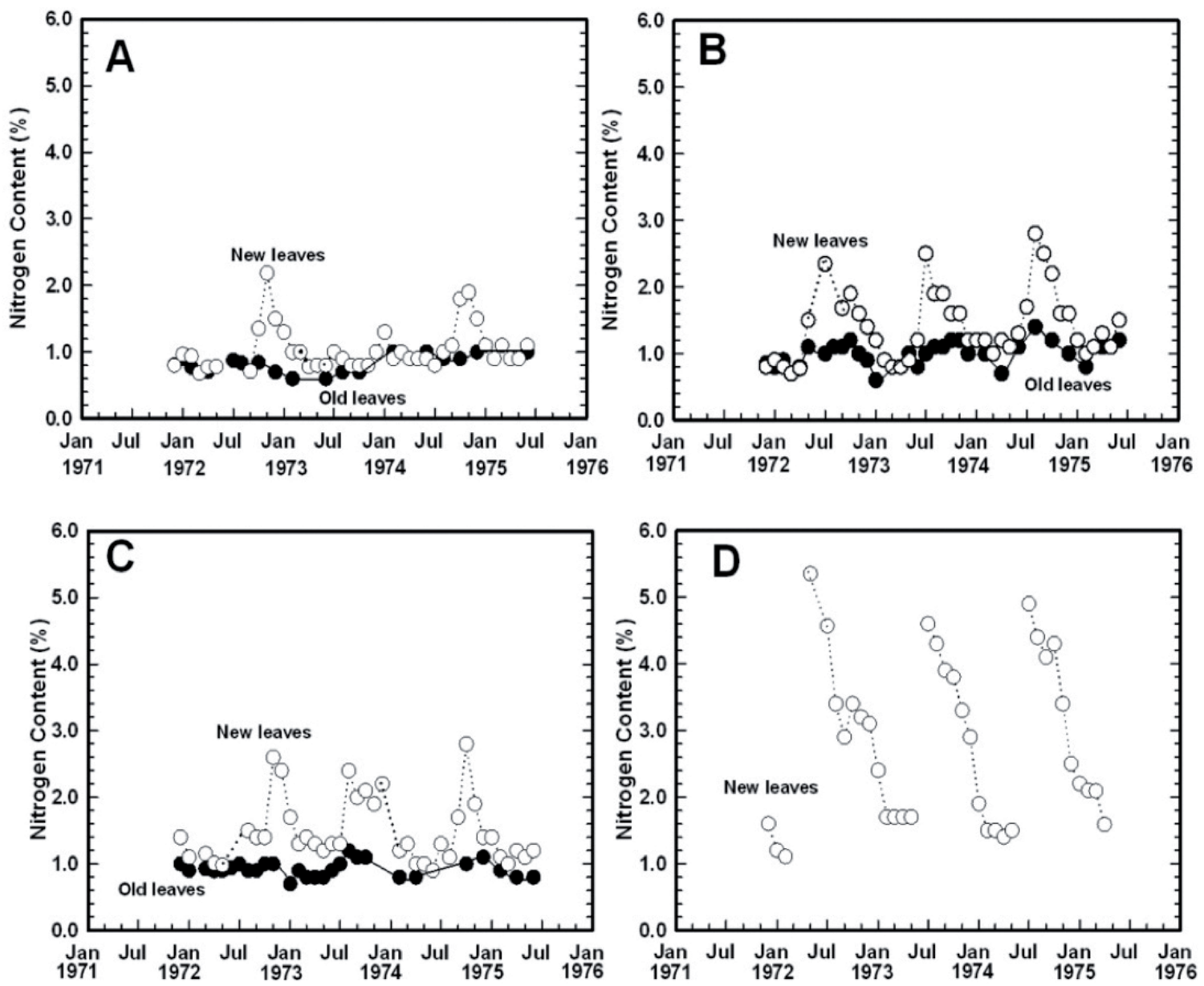

FIGURE 6. Seasonal change in total nitrogen content of old and new leaves of Lithrea caustica (A), Colliguaja odorifera (B), Kageneckia oblonga (C), and Retanilla trinervia (D). Old leaves of Retanilla were not measured due to the ephemerality of the leaves. / Cambio estacional en el contenido de nitrógeno total de hojas viejas y nuevas de Lithrea caustica (A), Colliguaja odorifera (B), Kageneckia oblonga (C) y Retanilla trinervia (D). Las hojas viejas de Retanilla no se midieron debido a lo efímero de las hojas. 

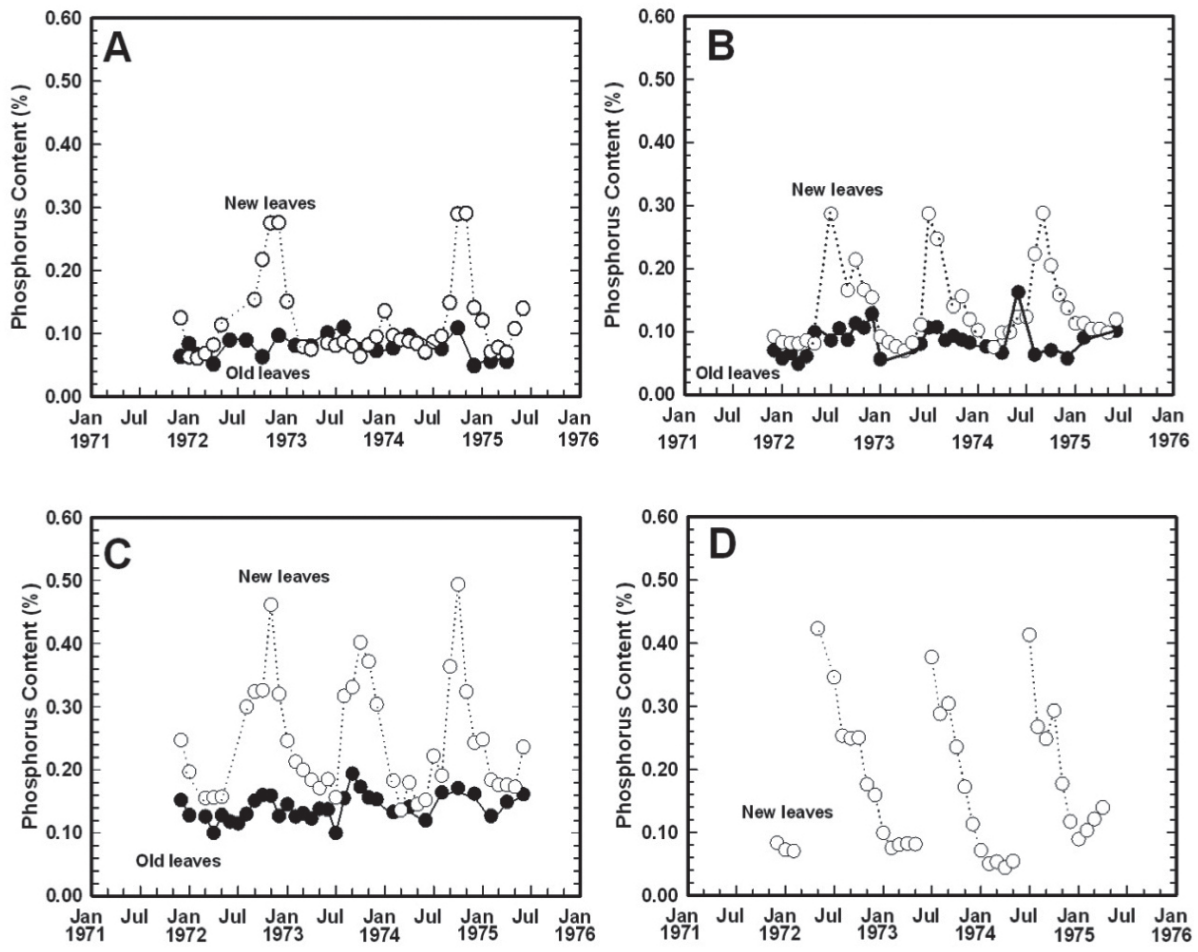

Figure 7. Seasonal change in total phosphorous content of old and new leaves of Lithrea caustica (A), Colliguaja odorifera (B), Kageneckia oblonga (C), and Retanilla trinervia (D). Old leaves of Retanilla were not measured due to the ephemerality of the leaves. / Cambio estacional en el contenido de fósforo total de hojas viejas y nuevas de Lithrea caustica (A), Colliguaja odorifera (B), Kageneckia oblonga (C) y Retanilla trinervia (D). Las hojas viejas de Retanilla no se midieron debido a lo efímero de las hojas.
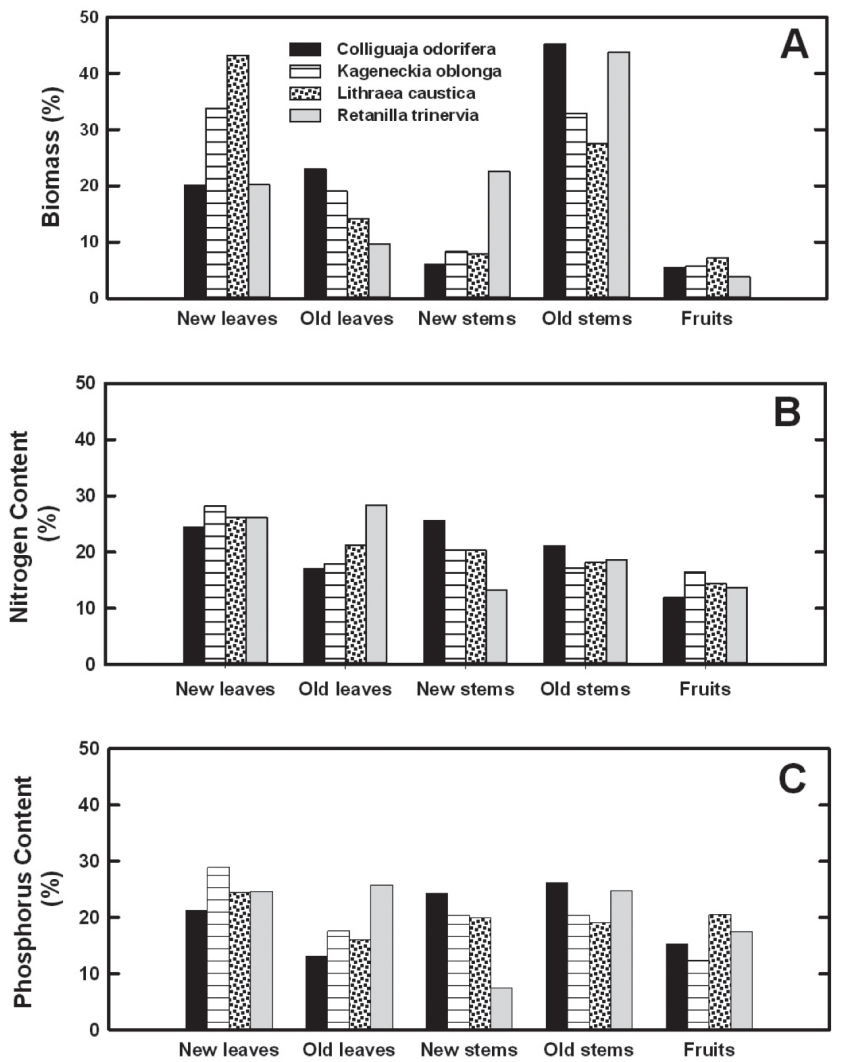

FIGURE 8. Relative allocation of biomass, nitrogen and phosphorus pools for four matorral shrub species. Biomass (A), nitrogen (B), and phosphorus $(\mathrm{C})$ contents are averages for each component from data collected over a four-year period. / Asignación relativa de biomasa ( $A$ ), nitrógeno $(B)$ y fósforo $(C)$ para las cuatro especies del matorral. La biomasa y los contenidos de nitrógeno y fósforo son promediados para cada componente a partir de los datos colectados durante un periodo de cuatro años. 
TABLE 2. Relative distribution of dry weight biomass, nitrogen, and phosphorus in aboveground canopy tissues. Data based on mean values for December over the four years of the study. / Distribución relativa de la biomasa seca, nitrógeno y fósforo en los tejidos del dosel. Datos basados en los valores promedio del mes de diciembre durante cuatro años de estudio.

\begin{tabular}{|c|c|c|c|c|}
\hline Species & Tissue & $\begin{array}{c}\text { Biomass } \\
\text { (\%) }\end{array}$ & $\begin{array}{c}\text { Nitrogen } \\
\text { (\%) }\end{array}$ & $\begin{array}{c}\text { Phosphorus } \\
\text { (\%) }\end{array}$ \\
\hline \multirow[t]{5}{*}{ Lithrea caustica } & new leaves & 43.2 & 25.1 & 24.5 \\
\hline & new stems & 7.9 & 20.3 & 19.8 \\
\hline & old leaves & 14.2 & 21.2 & 16.1 \\
\hline & old stems & 27.5 & 18.1 & 19 \\
\hline & reproductive tissues & 7.2 & 14.3 & 20.5 \\
\hline \multirow[t]{5}{*}{ Colliguaja odorifera } & new leaves & 20.1 & 24.4 & 21.3 \\
\hline & new stems & 6.12 & 25.6 & 24.3 \\
\hline & old leaves & 23 & 16.9 & 13.2 \\
\hline & old stems & 45.2 & 21.1 & 26 \\
\hline & reproductive tissues & 5.3 & 12 & 15.2 \\
\hline \multirow[t]{5}{*}{ Kageneckia oblonga } & new leaves & 33.8 & 28.3 & 28.9 \\
\hline & new stems & 8.4 & 20.3 & 20.5 \\
\hline & old leaves & 19.1 & 17.9 & 17.6 \\
\hline & old stems & 32.9 & 17.2 & 20.5 \\
\hline & reproductive tissues & 5.7 & 16.4 & 12.5 \\
\hline \multirow[t]{4}{*}{ Retanilla trinervia } & new leaves & 22.3 & 30.2 & 26.6 \\
\hline & new stems & 24.9 & 32.6 & 27.8 \\
\hline & old stems & 48.5 & 21.4 & 26.6 \\
\hline & reproductive tissues & 4.2 & 15.7 & 18.8 \\
\hline
\end{tabular}

\section{DISCUSSION}

Seasonal patterns of leaf flushing in the study species have been reported in previous studies (Montenegro et al. 1979a, Montenegro et al. 1982) and are expanded on here. The four matorral study species all showcased growth dynamics and nutrient relations similar to common chaparral species of southern California (Mooney et al. 1974). Lithrea began growth in March, later than other species but continued leaf growth well into the summer. This active summer growth differs from that of other most other matorral shrubs (Montenegro et al. 1979). Unlike most matorral shrubs, Lithrea flowers from axillary buds allowing vegetative growth to continue concurrent with or after flowering. Allocation of biomass to new leaves was also higher than in the other matorral shrubs
(Table 2). A deep and extensive root system helps to reduce summer drought stress in Lithrea (Giliberto \& Estay 1978, Hoffman \& Kummerow 1978, Poole \& Miller 1978). These growth dynamics of Lithrea do not seemed to be dependent on shallow pools of soil moisture, which is comparable to growth characteristics found in the deep-rooted species of the Californian chaparral community such as Rhus ovata and Malosma laurina (Kummerow et al. 1981). The leaves of Lithrea are scleromorphic with a leaf specific weight of $26 \mathrm{mg}$ $\mathrm{cm}^{-2}$ (Table 1) and are densely packed with palisade cells and a thick cuticle which forms a double layer on the upper leaf surface (Rundel 1981). These leaves had a longevity of up to four years.

Colliguaja and Retanilla with shallow root systems initiated leaf production in the late winter and spring, following a 
period of precipitation, indicating growth dynamics that are dependent on the availability and adequacy of soil moisture (Kummerow et al. 1981). In comparison to Lithrea, vegetative growth in Colliguaja begins early in late winter and ceases by early summer. Colliguaja is evergreen in the sense that leaves are always present, but leaf density is typically reduced by summer drought to half of that present at the end of the growing season (Hoffman \& Hoffman 1976). With its drought tolerance characteristics, Colliguaja began leaf production early in September and peaked in leaf production in early summer. Leaves not lost during the summer drought period are gradually abscised during the following growing season as new leaves are formed but this pattern of leaf replacement is highly variable depending on rainfall (Poiani \& del Pozo 1986). This makes for a shrub canopy with a relatively low leaf area index (Table 1) compared to other matorral evergreen shrubs. Relatively vertical leaf orientation in Colliguaja may be adaptive in reducing the absorption of solar radiation during the dry summer months (Roberts \& Miller 1977). Shoot growth is deterministic and vegetative shoots differentiate into reproductive tissues (Ginocchio \& Montenegro 1992). Root systems are shallow, resulting in relatively high water stress during the summer months and the associated cessation of growth (Giliberto \& Estay 1978, Poole \& Miller 1978, Hoffman \& Kummerow 1978).

Kageneckia has a phenology and leaf structure intermediate in many ways between Lithrea and Colliguaja in both the timing of initiation of leaf growth and period of leaf flushing (Montenegro et al. 1979a). Its seasonal cycle of leaf production and growth parallels that of Lithrea. It grows rapidly in the spring and early summer months, but leaf initiation slows as effective stomatal control occurs with the onset of summer drought (Mooney \& Kummerow 1971). The leaves are sclerophyllous with a thick double upper cuticle layer like that of Lithrea but the leaf specific weight of $21 \mathrm{mg} \mathrm{cm}^{-2}$ is somewhat lower than that of Lithrea or Colliguaja. (Table 1). As in Colliguaja and most matorral shrubs, vegetative growth is deterministic and vegetative shoot tips form reproductive tissues (Ginocchio and Montenegro 1992).

Leaves of Retanilla develop after fall rains from buds formed the previous spring at the end of the growing season (Hoffman 1972). In our study Retanilla began growth early in August with leaf flushing. These leaves have a low leaf specific weight of only $8 \mathrm{mg} \mathrm{cm}^{-2}$ and are lacking in xeromorphic characteristics. These leaves are drought-deciduous and abscised as water stress develops in the early summer months. After leaves are shed, low rates of shoot photosynthesis are maintained by the green stems of short shoots that are transformed into spines by lignification (Ginocchio \& Montenegro 1992). However, under late summer drought conditions much of the current year stems may also be shed. The seasonal phenology in many ways is similar to another small matorral shrub Gardoquia gilliesii Graham (Lamiaceae) but which maintains poikilohydic summer leaves (Montenegro et al. 1979b). Much of the ecological success of Retanilla comes from the ability to fix nitrogen through actinomycete root symbiosis (Rundel \& Neel 1978, Silvester et al. 1985) and from the thick seed coats that crack and germinate after fire.

Reproductive tissues represent a significant portion of the new biomass and nutrient allocation in all four matorral shrubs. Biomass allocation of new tissues (i.e. new leaves, new stems and reproductive tissues) ranged from $8.2 \%$ in Retanilla to $16.7 \%$ in Colliguaja. The nitrogen and phosphorus the heavy investment of resources to reproductive tissues was even more apparent (see data in Table 2). For nitrogen this allocation varied from $19.4 \%$ in Colliguaja to $25.2 \%$ in Kageneckia. For phosphorus the range was $25.6 \%$ in Retanilla to $31.6 \%$ in Lithrea. These high levels of new biomass and nutrient allocation to reproductive tissues are similar to that reported for Adenostoma fasciculatum in the California chaparral (Mooney \& Rundel 1979).

\section{Conclusions}

The vegetative and reproductive growth of matorral shrubs is influenced by a variety of abiotic and biotic influences, with available soil moisture, and temperature as the most important factors. A mediterranean-type climate presents strong challenges as soil moisture is most available in the winter months when temperatures are lower than those optimal for growth, while favorable warm temperatures occur in summer when drought conditions prevail as in California chaparral (Davis \& Mooney 1986, Keeley \& Davis 2007, Parker et al. 2016). It is not surprising, then, that the peak growing season for most shrubs is in spring, when temperatures and photoperiod increase and soils are still moist (Mooney et al. 1977).

Like California chaparral, evergreen matorral shrubs use an ecophysiological strategy based on evergreen leaves that are able to photosynthesize throughout the year in the relatively moderate thermal climate in which they grow (Miller, 1981). However, a general trade-off in having thick sclerophyllous leaves is that maximum rates of net assimilation are relatively low compared to those of thinner and less leathery leaf structure. During the dry summer as water becomes less available, shallow-rooted matorral shrubs reduce their rates of carbon fixation by stomatal control, to reduce loss of water through transpiration, while deeply-rooted shrubs such as Lithrea are able to continue active photosynthesis and growth well into the summer drought period (Miller 1981).

Matorral shrubs exhibit diverse phenological strategies 
related to their rooting architecture and leaf structure. While matorral shrubs are commonly characterized by having the functional trait of evergreen sclerophyllous leaves in contrast to the drought-deciduous leaves that characterize a few species such as Retanilla trinervia, leafing phenology is more complex. Evergreenness is not a simple trait but instead comes with multiple forms of leaf retention and levels of sclerophylly. The classic matorral shrub maintains two years of leaves, as with most evergreen species of matorral including Lithrea and Kageneckia, shedding the older set soon after or at the same time as new leaves are formed in spring. Although evergreen in the sense that it maintains a leaf canopy throughout the year, Colliguaja differs from the typical matorral phenology in retaining only a single cohort of leaves for most of the year.

\section{ACKNOWLEDGEMENTS}

Parts of this study were supported by the National Science Foundation awards GB27151 and DEB7519491. We thank the many people who were involved in the collection and processing of the plant and soil samples. In particular, we thank Celia Chu for the analysis of the 1973 plant samples and Jochen Kummerow and William Jow for their considerable help with logistics.

\section{REFERENCES}

Aschmann, H., Bahre, C. 1977. Man's impact on the wild landscape. In: Mooney, H.A. (ed.). Convergent evolution in Chile and California: Mediterranean climate ecosystems. pp. 73-84. Dowden Hutchinson and Ross. Stroudsburg, Pennsylvania.

Cowling, R.M., Rundel, P.W., Lamont, B.B., Arroyo, M.K., Arianoutsou, M. 1996. Plant diversity in Mediterraneanclimate regions. Trends in Ecology \& Evolution 11(9): 362-366.

Davis, S. D., Mooney, H.A. 1986. Water use patterns of four cooccurring chaparral shrubs. Oecologia 70: 172-177.

Di Castri, F., Mooney, H.A. 1973. Mediterranean-type ecosystems: Origin coast of North America. In: Di Castri, F., Mooney, H.A. (eds.), Mediterranean type ecosystems: Origin and Structure, pp. 21-36. Springer-Verlag. Berlin.

Giliberto, J., Estay, H. 1978. Seasonal water stress in some Chilean matorral shrubs. Botanical Gazette 139(2): 236240.

Giliberto, J., Mooney, H.A., Kummerow, J. 1977. Shrub structure analysis. pp. 144-147. In: Thrower, N.J.W., Bradbury, D.E. (eds.), Chile-California Mediterranean Scrub Atlas.
Dowden Hutchinson and Ross. Stroudsburg, Pennsylvania. Ginocchio, R., Montenegro, G. 1992. Interpretation of metameric architecture in dominant shrubs of the Chilean matorral. Oecologia 90(3): 451-456.

Hoffman, A.E. 1976. Comparative morphological and ecophysiological aspects of two sclerophyllous Chilean shrubs. Flora 165: 223-234.

Hoffman, A., Kummerow, J. 1978. Root studies in Chilean matorral. Oecologia 32(1): 57-69.

Hoffmann, A., 1972. Morphology and histology of Trevoa trinervis (Rhamnaceae), a drought deciduous shrub from the Chilean matorral. Flora 161(5-6): 527-538.

Hoffman, A., Hoffman, A.E. 1976. Growth pattern and seasonal behavior of buds of Colliguaya odorifera, a shrub from the Chilean Mediterranean vegetation. Canadian Journal of Botany 54: 1767-1774.

Keeley, J. E., Davis, F.W. 2007. Chaparral. In: Barbour, M.G., Keeler-Wolf, T., Schoenherr, A.A. (eds.). Terrestrial Vegetation of California, pp. 339-366. University of California Press, Berkeley, California.

Kummerow, J., Montenegro, G., Krause, D. 1981. Biomass, phenology, and growth. In: Miller, P.C. (ed.) Resource Use by Chaparral and Matorral: A Comparison of Vegetation Function in Two Mediterranean Type Ecosystems, pp. 6996. Springer-Verlag, New York.

Miller, P.C. (ed.) 1981. Resource Use by Chaparral and Matorral: A Comparison of Vegetation Function in Two Mediterranean Type Ecosystems. Springer-Verlag, New York.

Miller, P.C., Bradbury, D.E. Hajek, E., LaMarche, V, Thrower, N.J.V. 1977. Past and present environment. In: Mooney, H.A. (ed.). Convergent Evolution in Chile and California: Mediterranean Climate Ecosystems, pp. 27-83. Dowden Hutchinson and Ross. Stroudsburg, Pennsylvania.

Montenegro, G., Aljaro, M.E., Kummerow, J. 1979a. Growth dynamics of Chilean matorral shrubs. Botanical Gazette 140(1): 114-119.

Montenegro, G., Aljaro, M.E., Walkowiak, A. Saenger, R. 1982. Seasonality, growth and net productivity of herbs and shrubs of the Chilean matorral. In: U.S. Department of Agriculture, Forest Service; Dynamics and Management of Mediterranean-Type Ecosystems. General Technical Report PSW-58, pp. 135-141. Pacific Southwest Forest and Range Experiment Station, Berkeley, California.

Montenegro, G., Hoffmann, A., Aljaro, M.E., Hoffmann, A.E. 1979b. Satureja gilliesii, a poikilohydric shrub from the Chilean mediterranean vegetation. Canadian Journal of Botany 57(11): 1206-1213.

Montenegro, G., Riveros, F., Alcalde, C. 1980. Morphological structure and water balance of four Chilean shrub species. Flora 170(5-6): 554-564. 
Mooney, H.A., Kummerow, J. 1971. The comparative water economy of representative evergreen sclerophyll and drought deciduous shrubs of Chile. Botanical Gazette 132: 245-252.

Mooney, H.A., Kummerow, J. 1977. Shrub structural analysis. In: Thrower, N.J.W., Bradbury, D. (eds.) Chile-California Mediterranean scrub atlas, pp. 144-147. Dowden, Hutchinson \& Ross, Pennsylvania.

Mooney, H.A, Kummerow, J., Johnson, A.W., et al. 1977. The produces - their resources and adaptive responses. In: Mooney, H.A. (ed.). Convergent Evolution in Chile and California: Mediterranean Climate Ecosystems, pp. 85143. Dowden Hutchinson and Ross, Pennsylvania.

Mooney, H.A, Parsons, D., Kummerow, J. 1974. Plant development in Mediterranean climate. In: Lieth, H. (ed.). Phenology and Seasonality Modeling. pp. 254. Springer, Berlin.

Mooney, H.A., Rundel, P.W. 1979. Nutrient relations of the evergreen shrub, Adenostoma fasciculatum, in the California chaparral. Botanical Gazette 140(1): 109-113.

Nilsen, E.K., Schlesinger, W.H. 1981. Phenology, productivity, and nutrient accumulation in the post-fire chaparral shrub Lotus scoparius. Oecologia 50: 217-224.

Parker, V.T., Pratt, R.B., Keeley, J.E. 2016. Chaparral. In: Mooney, H.A., Zavaleta, E. (eds.). Ecosystems of California: A Source Book, pp. 479-508. University of California Press, Berkeley, USA.

Poiani, A., del Pozo, A. 1986. Efectos de la defoliación experimental sobre la producción de semillas y el crecimiento de Colliguaya odorifera Mol., Euphorbiaceae. Revista Chilena de Historia Natural 59: 39-45.

Poole, D.K., Miller, P.C. 1978. Water-related characteristics of some evergreen sclerophyll shrubs in central Chile. Oecologia Plantarum 13: 289-299.

Roberts, S.W., Miller, P.C. 1977. Interception of solar radiation as affected by canopy organization in two Mediterranean shrubs. Oecologia Plantarum 12: 273-290.

Rundel, P.W. 1981. The matorral zone of central Chile. In: di Castri, F., Goodall, D., Specht, R. (eds.) MediterraneanType Shrublands, pp. 175-201. Elsevier Publ., Amsterdam.

Rundel, P.W. 1982. Nitrogen use efficiency in Mediterraneanclimate shrubs of California and Chile. Oecologia 55: 409-413.

Rundel, P.W. 2018. California chaparral and its global significance. In: Underwood, E., Safford, H., Molinari, N., Keeley, J. (eds.). Valuing Chaparral, pp. 1-27. Springer Series on Environmental Management. Springer, Cham.

Rundel, P.W., Arroyo, M., Cowling, R.M., Keeley, J.E., Lamont, B.B., Vargas, P., 2016. Mediterranean biomes: evolution of their vegetation, floras, and climate. Annual Review of Ecology, Evolution, and Systematics 47: 383-407.

Rundel, P.W., Neel, J.W. 1978. Nitrogen fixation by Trevoa trinervis (Rhamnaceae) in the Chilean matorral. Flora 167(2): 127-132.

Silvester, W.B., Balboa, O., Martinez, J.A. 1985. Nodulation and nitrogen fixation in members of the Rhamnaceae (Colletia, Retanilla, Talguenea and Trevoa) growing in the Chilean matorral. Symbiosis (USA) 1: 29-38.

Steward, D., Webber, P.J. 1981. The plant communities and their environment. In: Miller, P.C. (ed.). Resource Use by Chaparral and Matorral: A Comparison of Vegetation Function in Two Mediterranean Type Ecosystems. pp. 43-68. Springer-Verlag, New York.

Received: 09.06.2019

Accepted: 17.09.2019 